\begin{tabular}{|c|c|c|}
\hline Received: 26-03-2021 & Revised: $28-10-2021$ & Published: 30-10-2021 \\
\hline (Date-Month-Year) & (Date-Month-Year) & (Date-Month-Year) \\
\hline
\end{tabular}

\title{
PENERAPAN PENDEKATAN PROBLEM SOLVING MODEL POLYA UNTUK MENINGKATKAN HASIL BELAJAR MATEMATIKA
}

\author{
Achmad Bachrul Anam ${ }^{1}$, Retno Marsitin $^{2}$, Nyamik Rahayu Sesanti $^{3}$ \\ 1,2,3 Pendidikan Matematika, Universitas PGRI Kanjuruhan Malang \\ 1 achmad.anam.aa@gmail.com \\ mars_retno@unikama.ac.id \\ ${ }^{3}$ nyamik@unikama.ac.id
}

\begin{abstract}
Abstrak: Penelitian ini bertujuan untuk mendeskripsikan langkah-langkah model polya untuk meningkatkan hasil belajar peserta didik. Penelitian dilaksanakan di SMP Modern AlRifa'ie Malang pada peserta didik kelas VIII-D dengan menggunakan subjek sebanyak 28 peserta didik tahun ajaran 2020/2021. Jenis penelitian yang digunakan dalam penelitian ini adalah Penelitian Tindakan Kelas (PTK) dengan pendekatan kualitatif. Hasil penelitian ini menunjukkan bahwa, adanya peningkatan hasil belajar peserta didik aspek kognitif pada setiap siklus. Persentase ketuntasan rata-rata yang diperoleh pada siklus I yaitu $34 \%$ sedangkan persentase ketuntasan rata-rata pada siklus II yaitu $80 \%$. Jadi persentase peningkatan yang terjadi pada siklus I dan II yaitu $46 \%$.
\end{abstract}

Kata Kunci: Penelitian tindakan kelas, problem solving model polya, hasil belajar.

\begin{abstract}
This study aims to describe the steps of the polya model to improve student learning outcomes. The research research was conducted at SMP Modern Al-Rifa'ie Malang in class VIII-D students using 28 students as the subject for the 2020/2021 academic year. The type of research used in this research is classroom action research is classroom action research (PTK) with a qualitative approach. The results of this study indicate that, there is an increase in student learning outcomes in the cognitive aspects of each cycle. The average completeness percentage obtained in the first cycle was 34\%, while the average completeness percentage in the second cycle was $80 \%$. So the percentage of increase that occurred in cycles I and II was $46 \%$.
\end{abstract}

Keywords: classroom action research, problem solving model polya, learning outcomes.

\section{Pendahuluan}

Matematika merupakan salah satu mata pelajaran yang diajarkan pada setiap jenjang pendidikan. Pelajaran matematika dianggap pelajaram yang membosankan dan tidak menarik oleh peserta didik, hal ini disebabkan karena pelajaran matematika dirasakan sukar dan rumit. Seperti yang diungkapkan oleh Abdurrahman (2012) banyak yang memandang matematika sebagai bidang studi yang paling sulit. Hal ini menjadi stigma pikir yang ada pada diri peserta didik secara berkelanjutan. Peserta didik seringkali mengalami kesalahan dalam menyelesaikan soal matematika yang dapat mempengaruhi hasil belajar peserta didik.

Sebagaimana yang diungkapkan oleh Radatz dalam Blanco \& Garrote (2007) kesalahan peserta didik dalam menyelesaikan masalah matematika merupakan hasil atau produk dari pengalaman pembelajaran matematika sebelumnya. 
Berdasarkan hasil penelitian yang dilakukan oleh San Pedro (2014) menemukan bahwa peserta didik yang ceroboh dan mengalami kesalahan seringkali adalah peserta didik yang tampak antusias dalam belajar. Sebaliknya, peserta didik yang malas dan bosan selama pembelajaran mengalami kesalahan akibat kecorobohan lebih sedikit.

Dari permasalahan ini sebaiknya guru memberikan kebebasan peserta didik untuk menyelesaikan masalah.

Kebebasan penyelesaian masalah akan menambah kemampuan berpikir kreatif peserta didik (Ariyanti, 2017:2). Pembelajaran matematika bertujuan membantu peserta didik memahami konsep, menyelesaikan suatu masalah, dan menerapkan masalah matematika dalam kehidupan nyata karena peserta didik ketika diberikan pembelajaran berbasis masalah, tingkat kepekaan mereka untuk berpikir akan lebih tinggi dibanding dengan peserta didik yang hanya mengacu pada contoh yang diberikan oleh guru (Ariyanti, 2017:2). Pendapat di atas, menjelaskan bahwa kepekaan peserta didik pada pembelajaran berbasis masalah lebih tinggi daripada yang hanya mengacu pada contoh yang diberikan guru.

Pada penelitian ini ditemukan permasalahan matematika kelas VIII-D tentang materi yang dikatakan belum mampu diselesaikan dengan baik oleh peserta didik yaitu materi yang berkaitan dengan soal SPLDV (Sistem Persamaan Linier Dua Variabel) pada pembelajaran matematika. Hal ini dibuktikan dengan hasil wawancara dan observasi pada guru matematika kelas VIII-D SMP Modern Al-Rifa'ie Malang, bahwa dalam menerapkan pembelajaran matematika peserta didik mengalami kesulitan dalam memahami soal dan mengerjakannya.

Kesulitan peserta didik dalam memahami dan menyelesaikan soal matematika terlihat ketika peserta didik kebingungan untuk menentukan langkah penyelesaian soal matematika, peserta didik juga kerap mengalami kesalahan dalam melaksanakan perhitungan. Guru matematika tersebut juga menuturkan materi yang sulit dipahami oleh peserta didik yaitu tentang SPLDV (Sistem Persaman Linier Dua Variabel). Kesalahan dalam materi tersebut kebanyakan dari perhitungan, karena peserta didik tidak pernah memeriksa kembali hasil perhitungannya.

Berdasarkan kondisi tersebut, maka dibutuhkan suatu model untuk menerapkan pendekatan problem solving yang dapat membantu peserta didik dalam menentukan langkah penyelesaian soal, sehingga kemampuan penyelesaian soal matematika peserta didik dapat meningkat. Problem solving adalah belajar memecahkan masalah. Pada tingkat ini para anak didik belajar merumuskan dan memecahkan masalah, serta memberikan respons terhadap rangsangan yang menggambarkan atau membangkitkan situasi problematik yang mempergunakan berbagai kaidah yang telah dikuasainya agar peserta didik mampu mengembangkan kreativitas dalam memecahkan masalah matematika, memahami konsep, dan penalaran matematika (Kurniawati, 2017:174).

Dalam SPLDV soal biasa berbentuk cerita yang kontekstual, untuk menyelesaikan persoalan tersebut perlu adanya tahap memodelkan secara matematis atau merepresentasikan, baru selanjutnya soal tersebut dapat diselesaikan. Banyak peserta didik yang masih kesulitan mempelajari materi SPLDV. Dalam hal ini peneliti memutuskan untuk menerapkan pendekatan problem solving model polya sebagai alternatif penyelesaian materi SPLDV yang mempermudahkan peserta didik. Alasan menggunakan pemecahan masalah dengan model polya, karena model polya menyediakan kerangka kerja 
yang tersusun rapi untuk menyelesaikan masalah yang kompleks sehingga dapat membantu siswa dalam memecahkan masalah. Beberapa hasil penelitian yang telah dilakukan sebelumnya menunjukkan bahwa pemecahan model Polya efektif.

Hal tersebut diungkapkan oleh hidayah (2016) berdasarkan hasil penelitiannya tentang analisis kesalahan dalam menyelesaikan soal cerita SPLDV berdasarkan langkah penyelesaian Polya menyatakan bahwa jenis-jenis kesalahan yang dilakukan peserta didik dan faktor penyebab terjadinya kesalahan yang dilakukan peserta didik antara lain (1) kesalahan memahami soal (2) kesalahan menyusun rencana (3) kesalahan melaksanakan rencana dan (3) kesalahan memeriksa kembali solusi yang diperoleh.

Budhayanti (2008:8-9) juga menyatakan " model polya untuk mempermudah memahami dan menyelesaikan suatu masalah, terlebih dahulu masalah tersebut disusun menjadi masalah-masalah sederhana, lalu dianalisis (mencari semua kemungkinan langkah-langkah yang ditempuh), kemudian dilanjutkan dengan proses sintesis (memeriksa kebenaran setiap langkah yang dilakukan)". Langkahlangkah polya di atas dapat disederhanakan menjadi empat langkah yaitu memahami masalah, membuat rencana penyelesaian, melaksanakan rencana dan melihat kembali.

Berdasarkan pendapat tersebut dapat disimpulkan bahwa dalam pemecahan masalah diperlukan suatu prosedur yang dapat diaplikasikan pada soal atau masalah matematika. Adapun yang menjadi prosedur proses dalam pelaksanaan pemecahan masalah mulai dari memahami masalah, membuat rencana penyelesaian, melaksanakan rencana, dan melihat kembali.

\section{Metode Penelitian}

Jenis penelitian yang digunakan dalam penelitian ini adalah penelitian tindakan kelas dengan pendekatan kualitatif. Penelitian ini dilaksanakan di SMP Modern Al-Rifaie Malang pada kelas VIII-D dengan jumlah 28 peserta didik. Prosedur pengumpulan data yang digunakan peneliti dalam penelitian ini adalah sebagai berikut:

\section{Wawancara}

Wawancara dilakukan secara lisan pada guru matematika kelas VIII-D SMP Modern Al-Rifa'ie Malang dengan pertemuan tatap muka secara individual pada tanggal 16 Maret 2020. Teknik ini dilakukan untuk menghimpun data awal sebelum melakukan penelitian. Wawancara berisikan pertanyaan mengenai kesulitan yang dirasakan oleh guru dalam proses pembelajaran dan data yang dihasilkan akan dijadikan tolak ukur penelitian.

\section{Observasi}

Observasi awal dilakukan pada tanggal 18 Maret 2020 pada siswa kelas VIII-D SMP Modern Al-Rifa'ie dengan cara pengamatan dan pencatatan mengenai pelaksanaan pembelajaran guru matematika di kelas. Observasi yang dilakukan yaitu observasi untuk aktivitas guru dalam mengajar dan observasi aktivitas peserta didik. Selain menggunakan instrumen berupa lembar observasi peneliti juga menggunakan catatan lapangan. Catatan lapangan dimaksudkan sebagai pelengkap data yang digunakan untuk mendeskripsikan kegiatan pembelajaran yang meliputi aktivitas guru dan peserta didik yang tidak terdapat dalam lembar observasi.

3. Tes

Tes digunakan untuk mengetahui atau mengukur kemampuan objek yang diteliti. Tes berupa tes tulis berbentuk uraian yang diberikan pada setiap pertemuan di setiap siklus. Tes pada pertemuan 1 siklus I dilaksanakan pada 22 Juli 2020, sedangkan untuk tes pertemuan 
2 siklus I dilaksanakan pada 23 Juli 2020. Adapun tes pada pertemuan 1 siklus II dilaksanakan pada 29 Juli 2020, sedangkan untuk tes pertemuan 2 siklus II dilaksanakan pada 30 Juli 2020. Melalui hasil tes tersebut dapat diketahui perbedaan hasil belajar peserta didik pada setiap siklus pada materi sistem persamaan linier dua variabel. Pemberian tes tulis juga bertujuan untuk mengetahui hasil belajar peserta didik setelah mengikuti pembelajaran problem solving model polya.

\section{Dokumentasi}

Kegiatan dokumentasi digunakan untuk mendokumentasikan kegiatan guru dan peserta didik saat proses penelitian berlangsung. Kegiatan ini dilakukan untuk melengkapi informasi yang dibutuhkan saat penelitian.

\section{Hasil dan Pembahasan}

Tahapan analisis mencakup reduksi data, penyajian data, penarikan kesimpulan.

Pada tahap reduksi data, data yang diperoleh meliputi data hasil tes akhir, catatan hasil observasi aktivitas guru dan peserta didik selama pembelajaran, dan catatan lapangan. Setelah itu tahap penyajian data dari hasil reduksi data secara naratif, sehingga memungkinkan penarikan kesimpulan dan pengambilan tindakan.

Dalam penelitian ini, peneliti menggunakan model PTK dengan siklus untuk mengetahui peningkatan dalam proses penelitian. Jika dalam penelitian dianggap sudah sesuai dengan yang diharapkan, maka siklus dapat dihentikan. Apabila dianggap masih belum berhasil, maka akan dilanjutkan ke siklus berikutnya.

Berikut paparan hasil penelitian pada setiap siklus:

\section{Siklus I pertemuan I}

\section{a) Kegiatan Awal}

Pada tahap ini peneliti memberikan salam, mengecek kehadiran peserta didik, dan menyampaikan apersepsi. Setelah melaksanakan apersepsi, peneliti menginformasikan tujuan dan langkahlangkah pembelajaran yang akan dilaksanakan. Selanjutnya, peneliti memberikan motivasi kepada peserta didik agar dapat mengetahui manfaat mempelajari materi Sistem Persamaan Linier Dua Variabel (SPLDV). Beberapa peserta didik terlihat antusias dalam menjawab pertanyaan yang disampaikan oleh peneliti terkait manfaat yang diperoleh. Berikut kutipan dialognya.

\section{b) Kegiatan Inti}

Peneliti mengawali kegiatan inti dengan membagi peserta didik menjadi 7 kelompok heterogen. Pembagian kelompok berdasarkan arahan guru karena guru matematika tersebut telah mengetahui kemampuan masing-masing peserta didik. Peneliti memanggil nama-nama peserta didik dan meminta untuk menempati meja yang telah ditentukan. Pada awal pembentukan kelompok, peserta didik gaduh mencari teman sekelompoknya. Peneliti membantu peserta didik mencari anggota kelompoknya dengan memanggil anggota tiap kelompok dan mengarahkan ke meja yang sudah ditentukan. Setelah menemukan teman sekelompoknya, peserta didik mulai tenang. Setelah kelompok terbentuk, peneliti membagikan rangkuman dan membahas materi Sistem Persamaan Linier Dua Variabel (SPLDV).

\section{c) Kegiatan Penutup}

Pada tahap ini, peneliti mengajak peserta didik menyimpulkan materi pembelajaran yang sudah dipelajari dengan cara tanya jawab.

Berikut hasil lembar kerja siswa : 


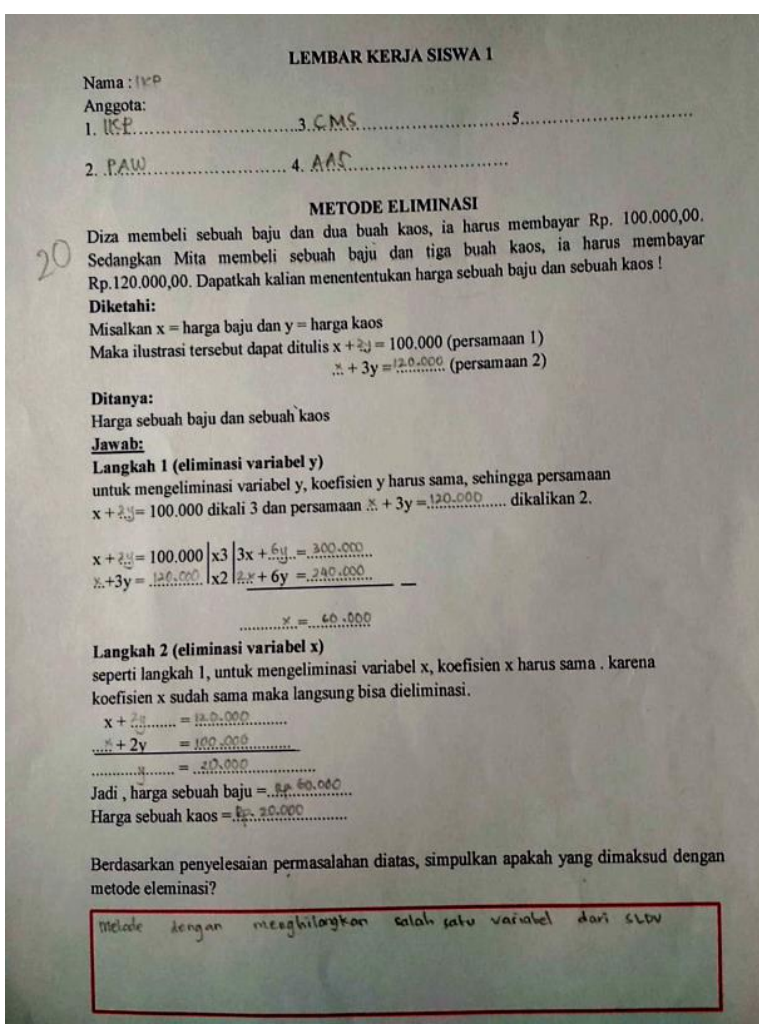

Gambar 1. Hasil tes subjek IKP

IKP :"pak, ini nggak ada jawabannya sih Pak? Ini kita sudah nyari tapi belum ada"

Peneliti :"IKP ayo coba dihitung kembali, mungkin ada yang terlewat"

IKP :"Oalah Pak, ini lo ada yang belum dihitung. (sambil menghitung kembali) Sudah ketemu Pak"

Jadi kesimpulannya, bahwa menghitung kembali dengan teliti suatu jawaban itu sangatlah penting agar tidak terjadi kesalahan. Setelah menghitung kembali dengan teliti akhirnya jawabannya ditemukan.

\section{Siklus I pertemuan 2}

\section{a) Kegiatan Awal}

Pada tahap ini peneliti memberikan salam, mengecek kehadiran peserta didik, dan menyampaikan apersepsi.

\section{b) Kegiatan Inti}

Peneliti mengawali kegiatan inti dengan meminta peserta didik untuk duduk di tempat masing-masing. Setelah suasana kelas tenang, peneliti membagikan rangkuman dan membahas materi Sistem Persamaan Linier Dua Variabel (SPLDV). Peneliti menjelaskan kembali tentang cara penyelesaian SPLDV dengan menggunakan polya. Peneliti menjelaskan langkah-langkah menggunakan polya. Setelah itu, peneliti memanggil beberapa peserta didik secara acak untuk mengambil soal untuk dipahami dan dikerjakan di papan tulis untuk melihat kepahaman peserta didik sudah sampai mana.

\section{c) Kegiatan Penutup}

Pada tahap ini, peneliti mengajak peserta didik menyimpulkan materi pembelajaran yang sudah dipelajari dengan cara tanya jawab.

Berikut hasil lembar kerja siswa :

Tentukan himpunan penyelesaian dari sistem persamaan $2 x+y=5$ dan $3 x-$ $2 \mathrm{y}=4$ dengan metode eliminasi jika $\mathrm{x}, \mathrm{y}$ variabel pada himpunan bilangan real !

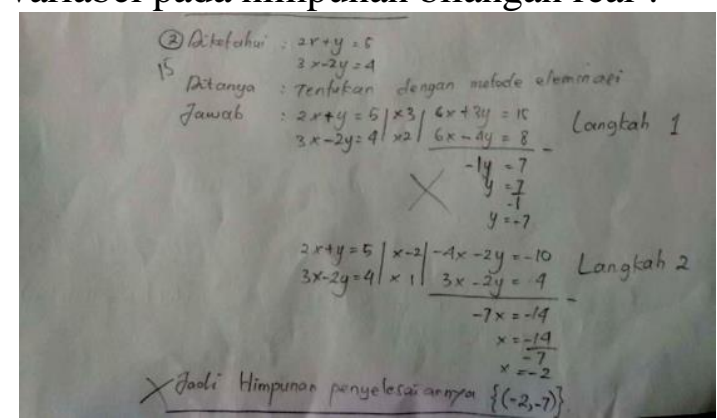

Gambar 2. Hasil tes subjek CMS

Peneliti :"Apakah jawaban CMS sudah benar?

Peserta didik :"Masih ada yang salah pak" (beberapa peserta didik serentak menjawab).

Peneliti :"Tolong DNP maju ke depan untuk membenarkan bagian yang salah".

DNP :"Iya pak".

Peneliti :"Apakah jawaban DNP sudah benar?

Peserta didik:"Sudah pak" (beberapa peserta didik serentak menjawab).

Peneliti :"Letak kesalahannya CMS tadi pada bagian melaksanakan 
rencana yaitu pada hasil hitungan, jadi kita harus hatihati dalam menghitung hasil dengan cara menghitung secara berulang-ulang untuk memastikan bahwa hitungan tersebut sudah benar. Dari sini paham?

Peserta didik :"Paham pak" (peserta didik serentak menjawab).

Jadi kesimpulannya, harus dengan teliti dalam menghitung agar dapat meminimalisir terjadinya jawaban yang salah.

\section{Siklus II pertemuan 1}

\section{a) Kegiatan Awal}

Pada tahap ini, peneliti mengawali pembelajaran dengan mengucapkan salam, mengecek kehadiran peserta didik, kemudian melakukan apersepsi.

\section{b) Kegiatan Inti}

Pada tahap ini peneliti membagi peserta didik menjadi 7 kelompok heterogen. Anggota kelompok yang dibentuk berbeda dengan kelompok pada siklus I. Setiap kelompok terdiri atas 4 peserta didik yang dikelompokkan berdasarkan hasil akhir tes siklus I.

\section{c) Kegiatan Penutup}

Pada kegiatan ini, peneliti membantu peserta didik menyimpulkan pembelajaran.

Berikut hasil lembar kerja siswa :

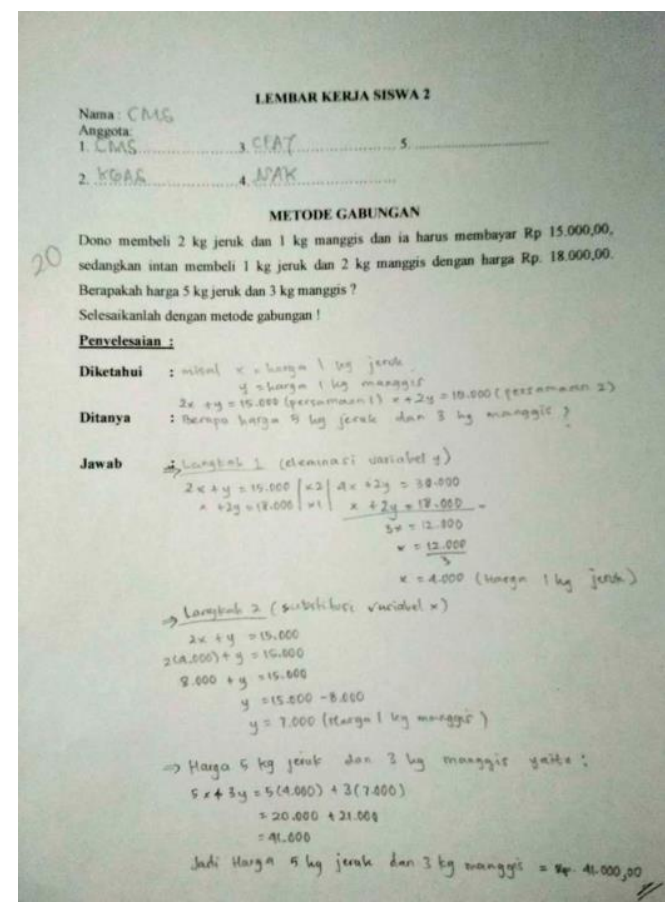

Gambar 3. Hasil tes subjek CMS

Peneliti :"CMS silahkan kerjakan soal tersebut dengan metode gabungan di depan dan jelaskan kepada temantemanmu".

CMS :(mulai mengerjakan soal yang diberikan dan menjelaskan kepada teman-temannya) "Begini Pak, sebelumnya kita rencanakan pemecahan masalahnya misalkan harga $1 \mathrm{~kg}$ jeruk itu sama dengan $\mathrm{x}$ dan harga $1 \mathrm{~kg}$ manggis sama dengan y. Kemudian kita cari diketahui, ditanya, dan dilaksanakannya perencanaan masalah dengan menjawabnya menggunakan model matematika dengan metode gabungan yaitu eleminasi dan substitusi ". Setelah itu di cek kebenarannya pak".

Peneliti :"Iya kamu benar". Silahkan berikan apresiasi pada CMS karena telah mengerjakan soal dan menjelaskan dengan sangat baik".

Peserta didik: (tepuk tangan).

Peneliti memberikan penguatan dan pemantapan pada hasil jawaban peserta didik, bahwa sebelumnya harus merencanakan pemecahan masalahnya cari diketahui, ditanya, dan dilaksanakannya 
perencanaan

menjawabnya

masalah

menggunakan

dengan

matematika dengan

model

metode

substitusi,eleminasi maupun gabungan (eleminasi dan substitusi), setelah itu di cek kebenarannya.

\section{Siklus II pertemuan 2}

\section{a) Kegiatan Awal}

Pada tahap ini, peneliti mengawali pembelajaran dengan mengucapkan salam, mengecek kehadiran peserta didik, kemudian melakukan apersepsi.

\section{b) Kegiatan Inti}

Peneliti mengawali kegiatan inti dengan meminta peserta didik untuk duduk di tempat masing-masing. Setelah suasana kelas tenang, peneliti membagikan tes soal siklus II. Peneliti memberikan penguatan dan pemantapan pada hasil soal tes peserta didik pada siklus II , bahwa sebelum mengerjakan sebaiknya kita pahami dulu soalnya kemudian kita harus memahami dulu apa yang diketahui, ditanyakan, setelah itu menyelesaikan masalah dengan perencanaan yang telah ditentukan dan lagkah terakhirnya mengecek kebenarannya.

\section{c) Kegiatan Penutup}

Pada kegiatan ini, peneliti membantu peserta didik menyimpulkan pembelajaran hari ini. Peneliti juga menanyakan kesan peserta didik terhadap pembelajaran.

Pada siklus II pertemuan 2 peserta didik sudah banyak yang memahami materi SPLDV dengan menggunakan model polya yang mengakibatkan hasil belajar peserta didik meningkat.

Berikut pemaparan keberhasilan penelitian ini:

Berdasarkan hasil pengamatan oleh observer (guru matematika) pada pelaksanaan observasi aktifitas guru pada siklus I dan siklus II terdapat persentase hasil observasi aktifitas guru siklus I dan II yang terdapat pada tabel 1 berikut.
Tabel 1. Persentase hasil observasi aktifitas guru siklus I dan II

\begin{tabular}{c|cccc} 
& \multicolumn{2}{|c}{ Siklus I } & \multicolumn{2}{c}{ Siklus II } \\
\cline { 2 - 4 } & $\begin{array}{c}\text { Pertemuan } \\
1\end{array}$ & $\begin{array}{c}\text { Pertemuan } \\
2\end{array}$ & $\begin{array}{c}\text { Pertemuan } \\
1\end{array}$ & $\begin{array}{c}\text { Pertemuan } \\
2\end{array}$ \\
\hline $\begin{array}{c}\text { Persentase } \\
\text { skor }\end{array}$ & $92 \%$ & $95 \%$ & $98 \%$ & $98 \%$ \\
\hline $\begin{array}{c}\text { Persentase } \\
\text { rata-rata }\end{array}$ & \multicolumn{2}{c}{$94 \%$} & & \multicolumn{2}{c}{$98 \%$} \\
\hline $\begin{array}{c}\text { Persentase } \\
\text { peningkatan }\end{array}$ & & $4 \%$ & & \\
\hline
\end{tabular}

Tabel tersebut menunjukkan bahwa aktifitas pembelajaran yang dilakukan oleh peneliti dikatakan berhasil dengan predikat keberhasilan sangat tinggi.

Berdasarkan hasil pengamatan oleh observer (guru matematika) pada pelaksanaan observasi aktifitas peserta didik pada siklus I dan siklus II terdapat persentase hasil observasi aktifitas peserta didik siklus I dan II yang terdapat pada tabel 2 berikut.

Tabel 2. Persentase hasil observasi aktifitas guru siklus I dan II

\begin{tabular}{|c|c|c|c|c|}
\hline & \multicolumn{2}{|c|}{ Siklus I } & \multicolumn{2}{|c|}{ Siklus II } \\
\hline & $\begin{array}{l}\text { Pertemuan } \\
1\end{array}$ & $\begin{array}{l}\text { Pertemuan } \\
2\end{array}$ & $\begin{array}{c}\text { Pertemuan } \\
1\end{array}$ & $\begin{array}{c}\text { Pertemuan } \\
2\end{array}$ \\
\hline $\begin{array}{l}\text { Persentase } \\
\text { skor }\end{array}$ & $64 \%$ & $82 \%$ & $91 \%$ & $100 \%$ \\
\hline $\begin{array}{c}\text { Persentase } \\
\text { rata-rata }\end{array}$ & \multicolumn{2}{|c|}{$73 \%$} & \multicolumn{2}{|c|}{$96 \%$} \\
\hline $\begin{array}{c}\text { Persentase } \\
\text { peningkatan }\end{array}$ & \multicolumn{4}{|c|}{$23 \%$} \\
\hline
\end{tabular}

Tabel tersebut menunjukkan bahwa aktifitas pembelajaran yang diikuti oleh peserta didik dikatakan berhasil dan termasuk dalam kategori sangat tinggi.

Berdasarkan hasil penelitian yang telah dilaksanakan pembahasan mata pelajaran matematika tentang sistem persamaan linier 2 variabel melalui pendekatan problem solving model polya pada peserta didik kelas VIII-D di SMP Modern Al-Rifa'ie Malang ketuntasan dari penilaian tes hasil belajar peserta didik pada setiap siklus terdapat pada tabel 3 berikut.

Tabel 3. Persentase hasil observasi aktifitas guru siklus I dan II

\begin{tabular}{|ccccc}
\hline \multirow{2}{*}{ Siklus I } & \multicolumn{2}{c}{ Siklus II } \\
\cline { 2 - 5 } & Pertemu & Pertemu & Pertemu & Pertemu \\
an 1 & an 2 & an 1 & an 2 \\
\hline
\end{tabular}




\begin{tabular}{ccccc}
\hline $\begin{array}{c}\text { Persentase } \\
\text { skor }\end{array}$ & $32 \%$ & $36 \%$ & $71 \%$ & $89 \%$ \\
\hline $\begin{array}{c}\text { Persentase } \\
\text { rata-rata }\end{array}$ & $34 \%$ & & $80 \%$ \\
\hline $\begin{array}{c}\text { Persentase } \\
\text { peningkatan }\end{array}$ & \multicolumn{4}{c}{$46 \%$} \\
\hline
\end{tabular}

Tabel tersebut menunjukkan bahwa pembelajaran dengan menggunakan model polya dapat meningkatkan hasil belajar peserta didik SMP Modern AlRifa'ie Malang dengan tingkat keberhasilan $\geq 80$ yang berarti sangat baik.

\section{Kesimpulan}

Penerapan problem solving model polya pada kelas VIII-D di SMP Modern Al-Rifa'ie Malang dapat membuktikan adanya peningkatan hasil penelitian pada setiap siklusnya. Peningkatan hasil belajar peserta didik dimana pada siklus I dengan persentase rata-rata klasikal 34\%, dan pada siklus II dengan rata-rata klasikal $80 \%$. Hasil tersebut juga menunjukkan bahwa penelitian tindakan kelas ini mencapai tingkat keberhasilan $\geq 80$ yang termasuk dalam kategori sangat baik/sangat tuntas.

\section{Daftar Rujukan}

Abdurrahman, M. (2012). "Anak berkesulitan belajar: teori, diagnosts, dan remedial". Jakarta: Rineka Cipta.

Ariyanti, S. (2017). Analisis Kemampuan Berpikir Kreatif Matematis Siswa
Kelas VII SMP Negeri 7 Kediri pada Materi Segi Empat. Simki-Techsain. 01(02):2.

Blanco and Garrote. (2007). "Difficulties in Learning Inequalities in Students of First Year of Pre-University Education in Spain". EJMSTE. 221229.

Budhayanti, Clara Ika Sari. (2008). Pemecahan Masalah Matematika. Direktorat Jendral Pendidikan tinggi.

Hidayah, S. (2016) "Analisis Kesalahan Peserta didik dalam Menyelesaikan Soal Cerita SPLDV Berdasarkan Langkah Penyelesaian Polya". Prosiding Seminar Nasional Pendidikan Matematika 2016Universitas Kanjuruhan Malang. Malang: 182-190.

Kurniawati, E. dkk. (2017). Pengaruh Model Pembelajaran Assurance, Relevance, Interest, Assesment, Satisfaction (Arias) Integratif dan Kemampuan Awal dalam Meningkatkan Pemahaman Konsep dan Pemecahan Masalah Matematika Siswa Sekolah Menengah Pertama Di Kepahiang. Jurnal Pendidikan Matematika Raflesia. 02(02):174.

San Pedro, M. O. Z., dkk. (2014). "Carelessness and Affectin an Intelligent Tutorung System for Mathematics". International Journal of Artificial Intelegence un education: 189-210. 